\title{
PENGARUH TINGKAT PENDIDIKAN, PENDAPATAN DAN KONSUMSI TERHADAP JUMLAH PENDUDUK MISKIN DI PROVINSI JAWA TIMUR
}

\author{
Fadlliyah Maulidah, Pascasarjana Unesa \\ fadlliyahmaulidah@gmail.com \\ Ady Soejoto, Universitas Negeri Surabaya \\ adysfe@yahoo.co.id
}

\begin{abstract}
ABSTRAK
Penelitian ini bertujuan untuk menganalisis pengaruh tingkat pendidikan, pendapatan dan konsumsi terhadap jumlah penduduk miskin di Provinsi Jawa Timur baik secara parsial maupun simultan. Populasi dalam penelitian ini adalah Provinsi Jawa Timur tahun 2009-2013. Teknik pengambilan sampel dengan teknik purposive sampling. Adapun metode pengumpulan data yang digunakan adalah metode dokumentasi. Sedangkan metode analisis menggunakan teknik analisis regresi data panel. Hasil analisis data menunjukkan bahwa secara parsial tingkat pendidikan tidak berpengaruh signifikan terhadap jumlah penduduk miskin Jawa Timur. Sedangkan pendapatan dan konsumsi berpengaruh signifikan terhadap jumlah penduduk miskin Jawa Timur. Sedangkan secara simultan tingkat pendidikan, pendapatan dan konsumsi berpengaruh signifikan terhadap jumlah penduduk miskin Jawa Timur.
\end{abstract}

Kata kunci: Jumlah Penduduk Miskin, Tingkat Pendidikan, Pendapatan, Konsumsi

\begin{abstract}
This research aims to analyze the influence of education level, income and consumption on the number of poor people in the east java province partially and simultaneously. The population of this research is poor people in east java province from the year 2009-2013. The technique of sampling applies purposive sampling. Furthermore, the method of data collection uses method of documentation while the method of data analysis is regression analysis techniques of panel data. The result of data analysis shows that in partial the education level does not influence significantly to the number of poor people of east java. However, the income and consumption influence significantly to the number of poor people of east java. Moreover, simultaneously the education level, income and consumption influence significantly to the number of poor people of east java. Keywords: The Number of Poor People, Education Level, Income, Consumption
\end{abstract}

\section{PENDAHULUAN}

Masalah kemiskinan merupakan masalah sedang dihadapi oleh banyak daerah di Indonesia. Jumlah penduduk miskin di Indonesia pada 2013 mencapai 28,5 juta jiwa atau $11,47 \%$ dari jumlah penduduk indonesia. Hal tersebut menunjukkan bahwa pembangunan ekonomi masih belum berhasil. Sebagaimana yang dijelaskan Todaro (2006) bahwa tujuan utama pembangunan ekonomi adalah 
untuk menciptakan pertumbuhan yang tinggi, namun selain itu harus pula mengurangi tingkat kemiskinan, kesenjangan pendapatan, dan tingkat pengangguran.

Badan pusat statistik (BPS) menjelaskan bahwa kemiskinan adalah ketidak mampuan memenuhi standar minimum kebutuhan, baik kebutuhan makanan maupun non makanan. Menurut BPS pula bahwa kemiskinan adalah kondisi seseorang yang hanya mampu memenuhi kebutuhan makannya kurang dari 2100 kalori perkapita perhari. Di Jawa Timur masih banyak penduduk yang tidak bisa memenuhi kebutuhan mereka. Masih banyak penduduk yang tidak dapat memenuhi kebutuhan makan mereka secara maksimal. Hal tersebut dapat dikarenakan pendapatan yang mereka miliki tidak cukup untuk memenuhi kebutuhan. Atau bisa juga karena mereka tidak memiliki pendapatan yang bisa dibelanjakan untuk kebutuhan mereka.

Berdasarkan data informasi kemiskinan dari BPS, di Jawa Timur pada tahun 2012 jumlah penduduk miskin Jawa Timur sebanyak 4,96 juta jiwa atau 13,08\% dari total penduduk Jawa Timur. Sedangkan pada 2013 memiliki jumlah penduduk miskin sebanyak 4,85 juta jiwa atau $12,73 \%$ dari total penduduk Jawa Timur. Jika dibandingkan tahun 2012 jumlah penduduk miskin di Jawa Timur mengalami penurunan sebesar $0,35 \%$. Akan tetapi jika dibandingkan dengan Provinsi lain yang dekat dengan Jawa Timur seperti Jawa Tengah dan DI Yogyakarta penurunan jumlah penduduk miskin di Jawa Timur paling kecil. Jawa Tengah mengalami penurunan sebesar $0,54 \%$ dan DI Yogyakarta mengalami penurunan sebesar $0,85 \%$. Hal tersebut menggambarkan bahwa Jawa Timur masih memiliki masalah penduduk miskin yang harus diselesaikan.

Kemiskinan disebabkan oleh banyak faktor, diantaranya dapat disebabkan oleh karena sulitnya memenuhi kebutuhan dasar, sulitnya memperoleh pendidikan dan pekerjaan. Sulitnya seseorang dalam memperoleh pendidikan akan menyebabkan seseorang kesulitan dalam mencari pekerjaan. Seiring perkembangan zaman lapangan kerja yang tersedia akan mencari tenaga kerja yang memiliki tingkat pendidikan yang tinggi. Jika dalam masa pendidikan banyak masyarakat yang tidak menempuh sebagaimana mestinya maka masyarakat tersebut akan mengalami kesulitan untuk mencari pekerjaan. Kesulitan mencari pekerjaan ini akan mengakibatkan seseorang kesulitan memperoleh pendapatan. Sehingga mereka tidak mampu untuk memenuhi kebutuhan hidup mereka.

Nurkse (dalam Kuncoro, 2006) menggambarkan dalam teori lingkar kemiskinan bahwa keterbelakangan, ketidaksempurnaan pasar, dan kurangnya modal dapat mengakibatkan rendahnya produktivitas manusia. Rendahnya produktivitas manusia akan mengakibatkan rendahnya pendapatan yang diterima. Rendahnya pendapatan yang diterima akan berakibat pada rendahya tabungan dan rendahnya investasi. Investasi bisa berupa investasi sumber daya manusia yaitu dengan ukuran pendidikan, maupun investasi kapital dengan ukuran konsumsi. Berdasarkan teori lingkaran kemiskinan tersebut dapat diketahui ada beberapa faktor yang menyebabkan kemiskinan diantaranya tingkat pendapatan, tingkat pendidikan, dan besarnya konsumsi.

Ada beberapa penyebab terjadinya kemiskinan yaitu, (1) Pekerjaan dan pendapatan, rendahnya tenaga kerja yang bekerja akan mengakibatkan pendapatan menurun sehingga kemiskinan meningkat. (2) Pendidikan, rendahnya pendidikan 
berhubungan dengan pengangguran dan konsekuensinya adalah menanggung resiko hidup dalam kemiskinan. (3) Kesehatan, orang yang hidup dalam kemiskinan cenderung lebih besar menderita penyakit baik fisik maupun mental. (4) Pengeluaran, masyarakat yang pengeluarannya rendah biasanya adalah masyarakat yang berada pada golongan miskin (Alchian, 2013).

Pendidikan diakui secara luas bahwa memiliki peran sebagai pemimpin dalam instrumen pertumbuhan ekonomi. Oleh karena itu pendidikan semakin dikembangkan. Beberapa tahun lalu pendidikan hanya dipusatkan pada pendidikan dasar dan menengah. Namun, saat ini pendidikan telah dikembangkan hingga pendidikan tinggi. Hal tersebut dilakukan karena pendidikan mampu memperbaiki kesejahteraan dan mengurangi kemiskinan (Bloom, 2006). Pendidikan memiliki peran penting dalam mengurangi kemiskinan baik di Negara Indonesia atau negara manapun dalam jangka panjang. Baik secara tidak langsung melalui perbaikan produktivitas dan efisiensi secara umum, maupun secara langsung melalui pelatihan golongan miskin dengan keterampilan yang dibutuhkan untuk meningkatkan produktivitas mereka dan pada waktunya akan meningkatkan pendapatan mereka (Arsyad, 2010).

Pendidikan merupakan salah satu cara untuk meningkatkan kualitas sumber daya manusia. Melalui pendidikan, pengetahuan seseorang akan bertambah yang akan bermanfaat untuk mempelajari keterampilan yang berguna di dunia kerja. Dengan demikian pendidikan dapat dimasukkan sebagai investasi pembangunan yang hasilnya dapat dinikmati di kemudian hari. Sebagaimana pembangunan di bidang lain, pendidikan menjadi salah satu bidang utama selain kesehatan dan ekonomi (BPS, 2013).

Menurut Gillis (2000) terdapat dua alasan mengapa pendidikan itu penting. Pertama karena banyak permintaan yang tinggi untuk pendidikan, hal ini terjadi karena banyak masyarakat yang percaya bahwa pendidikan yang tinggi akan memberikan keuntungan bagi mereka. Kedua, karena banyak hasil observasi yang menyatakan bahwa dengan tingkat pendidikan yang tinggi maka pendapatan dan status sosial di masyarakat akan terangkat. Menurut Ihsan (2011) tingkat pendidikan adalah tahap pendidikan yang bekelanjutan, yang ditetapkan berdasarkan perkembangan peserta didik, tingkat kerumitan bahan pengajaran dan cara menyajikan bahan pengajaran. Tingkat pendidikan sekolah terdiri dari pendidikan dasar, pendidikan menengah, dan pendidikan tinggi.

Menurut Badan Pusat Statistik (2013) pendidikan tertinggi yang ditamatkan, yaitu jenjang pendidikan tertinggi yang ditamatkan seseorang yang ditandai dengan ijazah. Persentase pendidikan yang ditamatkan dapat digunakan sebagai acuan perencanaan pembangunan yang digunakan untuk melakukan perencanaan penawaran tenaga kerja dengan menyesuaikan kualifikasi pendidikan yang ditamatkan oleh angkatan kerja di suatu wilayah.

Berdasarkan beberapa definisi di atas dapat disimpulkan bahwa pendidikan adalah suatu proses yang dilakukan oleh masyarakat dalam rangka meningkatkan kualitas sumber daya manusianya. Sehingga tingkat pendidikan dapat diartikan sebagai jenjang atau tingkat pendidikan yang ditempuh oleh masyarakat dalam rangka meningkatkan kualitas sumber daya manusia dengan ditandai diperolehnya ijazah.

Penelitian yang dilakukan Appleton (2001) menjelaskan bahwa kemiskinan yang terjadi di Uganda selama beberapa periode menjadikan 
kehidupan masyarakatnya terpuruk. Namun itu semua berakhir setelah adanya peningkatan tingkat pendidikan masyarakat. Dengan peningkatan pendidikan di sana membuat kehidupan masyarakat Uganda lebih berarti. Mereka memperoleh pekerjaan yang layak dengan upah yang sebanding. Sehingga mereka mampu meningkatkan kesejahteraan hidup mereka yang berdampak pada menurunnya kemiskinan.

Hasil penelitian yang sama juga dikemukakan oleh Doshi (2000) yang menyatakan bahwa pendidikan dapat mengurangi kemiskinan secara langsung yaitu dengan meningkatkan produktivitas bagi golongan miskin, memperbaiki kesempatan mereka untuk memperoleh pekerjaan dengan upah yang lebih baik. Dengan demikian pendidikan dapat mengurangi jumlah penduduk miskin yang ada. Tingkat pendidikan menjadi faktor penting yang mempengaruhi kemiskinan. Karena tingkat pendidikan akan mempengaruhi distribusi pendapatan yang pada akhirnya akan juga mempengaruhi kemiskinan. Jika semakin tinggi tingkat pendidikan maka distribusi pendapatan akan merata sehingga kemiskinan bisa berkurang.

Menurut Sukirno (2006) pendapatan adalah jumlah penghasilan yang diterima oleh penduduk atas prestasi kerjanya selama satu periode tertentu, baik harian, mingguan, bulanan atau tahunan. Pendapatan merupakan dasar dari kemiskinan. Pendapatan setiap individu diperoleh dari hasil kerjanya. Sehingga tinggi rendahnya pendapatan akan dijadikan seseorang sebagai pedoman kerja. Mereka yang memiliki pekerjaan dengan gaji yang rendah cenderung tidak maksimal dalam berproduksi. Sedangkan masyarakat yang memiliki gaji tinggi memiliki motivasi khusus untuk bekerja dan produktivitas kerja mereka lebih baik dan maksimal. Tanpa mereka sadari bahwa tindakan mereka ini akan merugikan diri mereka sendiri, karena dari hasil produktivitas tersebut mereka akan memperoleh pendapatan (Teal, 2001).

Salah satu nilai dasar yang dapat dijadikan konsep dasar untuk memahami pembangunan serta kaitannya dengan seseorang dikatakan miskin atau tidak adalah kecukupan memenuhi kebutuhan dasar. Kebutuhan dasar manusia tidak hanya menyangkut makanan, termasuk juga sandang, pangan, papan, kesehatan dan keamanan. Sedangkan untuk mencapai hal tersebut seseorang harus melakukan produktivitas agar bisa memperoleh penghasilan atau pendapatan yang nantinya akan digunakan untuk memenuhi kebutuhan dasar (Todaro, 2006).

Kondisi pendapatan dalam suatu negara (PDB) dapat diukur dengan tiga cara yaitu dengan Produk Nasional Bruto (GNP), Produk Nasional Neto (NNP), dan pendapatan nasional. Yang mana dari ketiga ukuran tersebut dapat memberikan informasi yang sama tentang kondisi perekonomian. Jika PDB mengalami kenaikan maka ketiga ukuran pendapatan tersebut juga akan mengalami kenaikan, begitu sebaliknya. Sehingga untuk melihat fluktuasi perekonomian dapat menggunakan ukuran pendapatan yang mana saja (Mankiw, 2013). Begitu pula dengan pendapatan dalam suatu daerah dapat diukur dengan melihat Produk Domestik Regional Bruto (PDRB). PDRB perkapita suatu wilayah belum bisa menggambarkan secara riil pendapatan yang diterima masing-masing penduduk karena masih dipengaruhi oleh produksi barang dan jasa. Sehingga digunakan pendekatan pendapatan perkapita yang dihitung dengan cara menghilangkan faktor bruto yang terdiri dari penyusutan dan pajak tidak langsung neto, serta ditambahkan pendapatan neto yang masuk wilayah tersebut, sehingga 
pendapatan perkapita dinilai lebih mendekati keadaan pendapatan sebenarnya di masyarakat (BPS, 2013).

Aspek pendapatan yang dapat digunakan sebagai indikator kemiskinan adalah pendapatan perkapita (Suryana, 2000). Pendapatan perkapita adalah pendapatan rata-rata penduduk suatu negara pada suatu periode tertentu, yang biasanya satu tahun. Pendapatan perkapita juga bisa diartikan sebagai jumlah dari nilai barang dan jasa rata-rata yang tersedia bagi penduduk suatu negara pada suatu periode tertentu. Pendapatan perkapita diperoleh dari pedapatan nasional pada tahun tertentu dibagi dengan jumlah penduduk suatu negara pada tahun tersebut (Sukirno, 2004). Berdasarkan beberapa penjelasan diatas maka pendapatan yang dimaksud dalam penelitian ini adalah pendapatan penduduk suatu daerah yaitu Provinsi Jawa Timur yang diukur dari pendapatan perkapita.

Hasil temuan Singh (2012) menyatakan bahwa pendapatan seseorang mampu menurunkan kemiskinan di suatu negara. Seperti yang ada di negara Asia bahwa pada tahun 1990 beberapa negara di Asia mengalami penurunan jumlah kemiskinan. Yang sebagian besar disebabkan karena adanya peningkatan dalam hal pendapatan. Demikian pula temuan dari Janjua (2011) yang menyatakan bahwa peningkatan pendapatan dapat menurunkan jumlah penduduk miskin. Karena dengan peningkatan pendapatan masyarakat bisa meningkatkan dalam hal pemenuhan kebutuhannya. Sehingga kesejahteraan masyarakat meningkat dan jumlah penduduk miskinnya menurun.

Salah satu tujuan ekonomi adalah untuk menjelaskan dasar-dasar perilaku konsumen. Mendalami tentang hukum permintaan dan mengetahui bahwa orangorang lebih cenderung membeli banyak barang ketika harga barang itu rendah dan sebaliknya (Samuelson, 2004). Konsumsi secara umum diartikan sebagai penggunaan barang dan jasa secara langsung untuk memenuhi kebutuhan manusia (Rosydi, 2002). Keynes mengemukakan bahwa konsumsi adalah fungsi positif dari pendapatan dan rumah tangga yang berpendapatan tinggi melakukan konsumsi pangan lebih sedikit dari rumah tangga yang berpendapatan rendah, karena pendapatannya yang lain dialokasikan pada konsumsi non pangan (dalam Case and Fair, 2002).

Menurut Wahyu (2011) konsumsi adalah kegiatan manusia menggunakan atau memakai barang atau jasa untuk memenuhi kebutuhan dengan tujuan untuk mencapai kepuasan maksimum dari kombinasi barang atau jasa yang digunakan. Mutu dan jumlah barang yang dikonsumsi dapat menggambarkan kemakmuran konsumen tersebut. Jika mutu dan jumlah barang yang dikonsumsi semakin tinggi, berarti semakin tinggi pula tingkat kemakmuran konsumen tersebut, begitu sebaliknya.

Konsumsi merupakan kegiatan menggunakan barang dan jasa untuk memenuhi kebutuhan sehari-hari. Jumlah dan mutu barang atau jasa yang dikonsumsi tersebut menggambarkan kemakmuran konsumen. Dan tujuan konsumsi adalah untuk mencapai kepuasan maksimum dari setiap barang yang digunakan (Nurhadi, 2000). Gan (2013) menyatakan bahwa konsumsi merupakan kegiatan menggunakan barang dan jasa untuk mengurangi atau menghabiskan nilai guna suatu barang dengan tujuan untuk memenuhi kebutuhan hidup setiap hari. Konsumsi yang dilakukan tersebut dapat menunjukkan kesejahteraan seseorang. 
Konsumsi yang dilakukan masyarakat bisa menjadi nilai sosial yang dipandang bahwa ketika seseorang mampu melakukan konsumsi dianggap mampu memenuhi kebutuhan dan dikategorikan sejahtera. Sedangkan mereka yang tidak mampu melakukan konsumsi dianggap tidak mampu memenuhi kebutuhan serta dikategorikan kurang sejahtera. Sehingga dikatakan konsumsi dapat mempengaruhi tinggi rendahnya kemiskinan masyarakat (Nicholls, 2000).

Konsumsi merupakan kemampuan seseorang untuk menukar energi dan uang mereka untuk memperoleh barang dan layanan (jasa) yang dapat memuaskan kebutuhan mereka. Konsumsi meliputi bermacam-macam tujuan dan konsekuensi yang terdiri dari makanan, kesenangan (hiburan), dan prestasi untuk memenuhi hak mereka agar mereka tidak putus asa (Blocker, 2011).

Berdasar dari beberapa pendapat di atas, dapat disimpulkan bahwa konsumsi adalah segala sesuatu barang dan jasa yang digunakan oleh seseorang untuk memenuhi kebutuhan hidupnya, baik dalam bentuk pangan maupun non pangan. Dalam penelitian ini akan menggunakan data konsumsi masyarakat Jawa Timur.

Hasil temuan Gan (2013) menunjukkan bahwa pada tahun 2008 di China terjadi peningkatan kemiskinan. Yang mana hal tersebut disebabkan karena menurunnya konsumsi yang dilakukan masyarakat. Demikian pula pada hasil penelitian Hurd (2006) menyatakan bahwa di Cambridge terjadi peningkatan kemiskinan ketika masyarakatnya mengalami kesulitan dalam mengkonsumsi kebutuhan hidupnya. Sejalan dengan itu temuan dari Moav (2008) juga menyatakan bahwa konsumsi yang dilakukan oleh warga London memiliki memiliki peran pada kegiatan ekonomi negaranya. Pada suatu periode warganya banyak melakukan konsumsi dan pada tahun tersebut ternyata terjadi penurunan jumlah penduduk miskin dari periode sebelumnya.

Berdasarkan pemaparan di atas maka tujuan penelitian ini antara lain: (a) Untuk menganalisis pengaruh tingkat pendidikan, pendapatan dan konsumsi terhadap jumlah penduduk miskin di Provinsi Jawa Timur secara parsial; (b) Untuk menganalisis pengaruh tingkat pendidikan, pendapatan dan konsumsi terhadap jumlah penduduk miskin di Provinsi Jawa Timur secara simultan.

\section{METODE PENELITIAN}

Penelitian ini tergolong penelitian kuantitatif. Dalam penelitian ini menggunakan metode korelasi untuk mencari pengaruh antara variabel bebas (independen) yaitu tingkat pendidikan $\left(\mathrm{X}_{1}\right)$, pendapatan $\left(\mathrm{X}_{2}\right)$, dan konsumsi $\left(\mathrm{X}_{3}\right)$ terhadap variabel terikat (dependen) yaitu jumlah penduduk miskin (Y). Populasi dalam penelitian ini adalah penduduk provinsi jawa timur yang terbagi dalam 38 kabupaten/kota pada tahun 2009-2013. Sedangkan teknik pengambilan sampel dalam penelitian ini menggunakan teknik purposive sampling yaitu teknik penentuan sampel dengan pertimbangan tertentu (Sugiyono, 2011). Pertimbangan yang digunakan adalah Kabupaten/Kota yang memiliki jumlah penduduk miskin sedang. Selanjutnya sampel diambil berdasarkan sampel area berdasarkan pembagian Bakorwil (Badan Kordinasi Wilayah) yang ada di Jawa Timur. Pengambilan sampel menggunakan perhitungan statistik dengan menentukan rentang kelas, banyak kelas dan panjang kelas (Sudjana, 2005). Sehingga diperoleh sampel 14 Kabupaten/Kota. 
Metode pengumpulan data yang digunakan dalam penelitian ini adalah metode dokumentasi. Karena data yang digunakan adalah data sekunder yang telah tersedia di Badan Pusat Statistik Provinsi Jawa Timur. Adapun metode analisis data yang digunakan adalah analisis dengan regresi data panel. Analisis regresi data panel ini digunakan untuk mengetahui besarnya hubungan antara variabel bebas dengan variabel terikat secara parsial dan simultan.

\section{HASIL DAN PEMBAHASAN}

Analisis dalam penelitian ini menggunakan analisis regresi data panel yang berfungsi untuk mengetahui ada tidaknya pengaruh signifikan pengaruh antara ketiga variabel bebas yaitu tingkat pendidikan $\left(\mathrm{X}_{1}\right)$, pendapatan $\left(\mathrm{X}_{2}\right)$ dan konsumsi $\left(\mathrm{X}_{3}\right)$ terhadap jumlah penduduk miskin $(\mathrm{Y})$. Persamaan regresi yang diperoleh adalah sebagai berikut: $\mathrm{Y}=255374,1-0,005138 \mathrm{X}_{1}-0,011916 \mathrm{X}_{2}-$ $0,003543 \mathrm{X}_{3}+$ ei. Dari persamaan tersebut dapat dijelaskan: 1.) Konstanta $(\alpha)$ adalah sebesar 255374,1 artinya jika tidak terjadi perubahan nilai pada variabel tingkat pendidikan $\left(\mathrm{X}_{1}\right)$, pendapatan $\left(\mathrm{X}_{2}\right)$ dan konsumsi $\left(\mathrm{X}_{3}\right)$ maka $\mathrm{Y}$ akan diperoleh adalah sebesar $255374,1 \%$; 2.) Koefisien dari variabel tingkat pendidikan adalah $-0,005$ artinya jika variabel tingkat pendidikan bertambah $1 \%$, sedangkan variabel lainnya tetap (pendapatan dan konsumsi), maka jumlah penduduk miskin akan mengalami kenaikan sebesar 0,005\%. Tanda (-) negatif menunjukkan adanya hubungan terbalik antara tingkat pendidikan dan jumlah penduduk miskin Jawa Timur. Jika tingkat pendidikan tinggi maka jumlah penduduk miskin akan menurun; 3.) Koefisien dari variabel pendapatan adalah 0,012 artinya jika variabel pendapatan bertambah $1 \%$, sedangkan variabel lainnya tetap (tingkat pendidikan dan konsumsi), maka jumlah penduduk miskin akan mengalami kenaikan sebesar $0,012 \%$. Tanda (-) negatif menunjukkan adanya hubungan terbalik antara pendapatan dan jumlah penduduk miskin Jawa Timur. Jika pendapatan tinggi maka jumlah penduduk miskin akan menurun; 4.) Koefisien dari variabel konsumsi adalah $-0,003$ artinya jika variabel konsumsi bertambah $1 \%$, sedangkan variabel lainnya tetap (tingkat pendidikan dan pendapatan), maka jumlah penduduk miskin akan mengalami kenaikan sebesar $0,003 \%$. Tanda (-) negatif menunjukkan adanya hubungan terbalik antara konsumsi dan jumlah penduduk miskin Jawa Timur. Jika konsumsi tinggi maka jumlah penduduk miskin akan menurun.

Selanjutnya dilakukan uji hasil persamaan regresi data panel, yang pertama dilakukan adalah uji signifikansi parsial (Uji t) ini digunakan untuk mengetahui apakah tiap variabel bebas secara parsial mempengaruhi variabel terikat (dependen). Dari hasil uji signifikansi parsial (uji t) diperoleh hasil sebagai berikut: 1.) Hasil Uji-t untuk variabel tingkat pendidikan terhadap jumlah penduduk miskin diperoleh nilai signifikansi sebesar $0,76>0,05$. Sehingga $\mathrm{H}_{0}$ diterima, artinya variabel tingkat pendidikan tidak mempunyai pengaruh signifikan terhadap jumlah penduduk miskin di Provinsi Jawa Timur; 2.) Hasil Uji-t untuk variabel pendapatan terhadap jumlah penduduk miskin diperoleh nilai signifikansi sebesar $0,0005<0,05$. Sehingga $\mathrm{H}_{0}$ ditolak, artinya variabel pendapatan mempunyai pengaruh signifikan terhadap jumlah penduduk miskin di Provinsi Jawa Timur; 3.) Hasi Uji-t untuk variabel konsumsi terhadap jumlah penduduk miskin diperoleh nilai signifikansi sebesar 0,029<0,05. Sehingga $\mathrm{H}_{0}$ 
ditolak, artinya variabel konsumsi mempunyai pengaruh signifikan terhadap jumlah penduduk miskin di Provinsi Jawa Timur.

Setelah dilakukan uji signifikansi parsial (uji t) kemudian dilakukan uji signifikansi simultan (uji f), ini digunakan untuk mengetahui apakah variabelvariabel independen secara bersama-sama mempengaruhi variabel dependen. Dari hasil uji signifikansi simultan (uji f) diperoleh hasil bahwa ketiga variabel bebas yaitu tingkat pendidikan, pendapatan dan konsumsi terhadap jumlah penduduk miskin memperoleh nilai signifikansi sebesar $0.000000<0,05$. Sehingga $\mathrm{H}_{0}$ ditolak, yang artinya variabel tingkat pendidikan, pendapatan dan konsumsi secara bersama-sama mempunyai pengaruh yang signifikan terhadap jumlah penduduk miskin di Provinsi Jawa Timur.

Setelah dilakukan uji signifikansi parsial (uji t) dan signifikansi simultan (uji f) akan diperoleh nilai koefisien determinasi $\left(\mathrm{R}^{2}\right)$. Koefisien determinasi ini digunakan untuk mengetahui seberapa besar kemampuan variabel bebas tingkat pendidikan, pendapatan dan konsumsi menjelaskan variabel terikat jumlah penduduk miskin. Koefisien determinasi $\left(\mathrm{R}^{2}\right)$ dapat dilihat pada tabel Model Summary $^{b}$ dan tertulis Adjusted $R$ Square. Adapun hasil koefisien determinasi adalah sebesar 0,992350. Hal ini berarti sebesar 99,23\% jumlah penduduk miskin di Provinsi Jawa Timur dapat dijelaskan ketiga variabel tersebut, yaitu variabel tingkat pendidikan, pendapatan dan konsumsi. Sedangkan sisanya sebesar $0,77 \%$ dipengaruhi oleh faktor-faktor lain di luar variabel penelitian.

Berdasarkan hasil analisis dengan menggunakan bantuan program Eviews 6 menunjukkan hasil bahwa tidak terdapat pengaruh signifikan antara tingkat pendidikan dengan jumlah penduduk miskin di Provinsi Jawa Timur. Hasil tersebut dibuktikan dengan hasil uji-t variabel tingkat pendidikan yang menunjukkan hasil sebesar 0,76 lebih besar dari taraf signifikansi 0,05. Selain itu hasil juga menunjukkan bahwa hubungan antara tingkat pendidikan dengan jumlah penduduk miskin di Provinsi Jawa Timur adalah negatif atau tidak searah yaitu $-0,005$. Artinya semakin tinggi tingkat pendidikan maka jumlah penduduk miskin Provinsi Jawa Timur akan menurun. Dan sebaliknya, jika semakin rendah tingkat pendidikan maka akan diikuti dengan meningkatnya jumlah penduduk miskin Provinsi Jawa Timur.

Hasil ini bertolak belakang dengan hasil penelitian sebelumnya yang dilakukan oleh Appleton (2001), Aksentijevic (2006), Ukwuezze (2014), Zakharia (2006) dan Capra (2009) yang menyimpulkan bahwa tingkat pendidikan memiliki pengaruh terhadap jumlah penduduk miskin. Selain bertolak belakang dengan hasil penelitian sebelumnya, hasil penelitian ini juga tidak sejalan dengan Teori yang dikemukakan oleh Bloom (2006) yang menyatakan bahwa pendidikan mampu memperbaiki kesejahteraan dan mengurangi kemiskinan. Demikian pula yang dikemukakan Arsyad (2010) yang menyatakan bahwa pendidikan memiliki peran penting dalam mengurangi kemiskinan di suatu negara baik secara langsung maupun tidak langsung.

Perbedaan hasil ini disebabkan karena di negara-negara tempat penelitian terdahulu di atas penduduknya mampu mengaplikasikan ilmu dan keterampilan yang mereka miliki dari hasil sekolah mereka. Kebanyakan dari mereka mampu mendirikan usaha sendiri setelah mereka bersekolah. Usaha yang mereka dirikan tidak hanya memberi manfaat bagi diri mereka sendiri akan tetapi juga memberi manfaat bagi masyarakat sekitarnya. Tidak sedikit masyarakat yang ikut 
dilibatkan dalam usaha mereka, sehingga pengangguran bisa berkurang. Dengan kondisi ini mereka dapat membantu masyarakat yang sebelumnya tidak berpenghasilan menjadi berpenghasilan.

Adanya perbedaan hasil penelitian ini tentunya disebabkan oleh beberapa hal. Seperti yang diungkapkan oleh Harbison (2000) yang menyatakan bahwa kondisi pendidikan berbeda di satu daerah dengan daerah lain. Perbedaan itu bisa disebabkan karena adanya perbedaan kondisi sosial ekonomi, sumber daya manusia, penduduk dan kesadaran masyarakat. Kondisi tingkat pendidikan pada penelitian ini juga demikian memiliki perbedaan antara daerah yang satu dengan yang lain.

Terdapat beberapa Kabupaten/Kota di Jawa Timur yang mengalami penurunan jumlah penduduk yang memiliki jenjang pendidikan minimal SMA. Kabupaten yang mengalami penurunan tingkat pendidikan disebabkan karena pada tahun di atas jumlah penduduk di Kabupaten tersebut juga mengalami penurunan pada penduduk usia 15 sampai 17 tahun, di mana usia tersebut adalah usia anak sekolah pada jenjang SMA sederajat.

Tingkat pendidikan terhadap jumlah penduduk miskin tidak memiliki pengaruh signifikan bukan hanya karena jumlah penduduk yang menurun, selain itu penduduk yang selesai menamatkan sekolahnya tidak semua bisa bekerja. Kebanyakan dari mereka memiliki keinginan bekerja menjadi karyawan kantor terlebih bagi mereka yang lulusan perguruan tinggi. Sedangkan lapangan kerja yang mereka inginkan jumlahnya terbatas. Sehingga tidak semua lulusan bisa bekerja. Berdasarkan penjelasan di atas dan data yang ada dapat diketahui bahwa menurunnya tingkat pendidikan ternyata diikuti dengan meningkatnya jumlah penduduk miskin, tetapi peningkatannya sangat kecil yaitu sekitar 0,004\%. Hal ini menunjukkan bahwa pengaruhnya sangat kecil atau tidak terdapat pengaruh yang signifikan. Temuan ini sejalan dengan temuan yang ditemukan oleh Brown dan Park (2002), Kambon (2000), Lacour (2011), dan Law and Poverty (2014) yang menyimpulkan bahwa tingkat pendidikan tidak memiliki pengaruh signifikan terhadap jumlah penduduk miskin.

Berdasarkan teori dan hasil penelitian di atas maka dapat dikatakan bahwa tingkat pendidikan yang tinggi tidak bisa menjamin berkurangnya jumlah penduduk miskin. Dengan demikian maka hipotesis penelitian ini yang menyatakan bahwa diduga tingkat pendidikan berpengaruh signifikan terhadap jumlah penduduk miskin Provinsi Jawa Timur tidak terbukti kebenarannya.

Berdasarkan hasil analisis dengan menggunakan bantuan program Eviews 6 menunjukkan hasil bahwa terdapat pengaruh signifikan antara pendapatan dengan jumlah penduduk miskin di Provinsi Jawa Timur. Hasil tersebut dibuktikan dengan hasil uji-t variabel pendapatan yang menunjukkan hasil sebesar 0,0005 lebih kecil dari taraf signifikansi 0,05. Selain itu hasil juga menunjukkan bahwa hubungan antara pendapatan dengan jumlah penduduk miskin di Provinsi Jawa Timur adalah negatif atau tidak searah. Sehingga semakin tinggi pendapatan maka jumlah penduduk miskin Provinsi Jawa Timur akan menurun. Dan sebaliknya, jika semakin rendah pendapatan maka akan diikuti dengan meningkatnya jumlah penduduk miskin Provinsi Jawa Timur.

Keadaan ini sejalan dengan penelitian sebelumnya yang dilakukan oleh Singh (2012), Gradin (2008), Rika (2012), Gerson (2002), Raphael (2002) dan Janjua (2011) yang menyimpulkan bahwa pendapatan dapat mempengaruhi 
kemiskinan. Selain sejalan dengan hasil penelitian tersebut hasil penelitian ini juga sesuai dengan teori yang dikemukakan Mankiw (2013) yang memaparkan bahwa naik turunnya pendapatan mempengaruhi fluktuasi perekonomian termasuk tinggi rendahnya kemiskinan suatu negara atau daerah.

Pendapatan perkapita beberapa Kabupaten di Jawa Timur dari 2009-2013 terus mengalami peningkatan. Peningkatan ini disebabkan oleh meningkatnya lapangan usaha terutama bidang restoran dan hotel serta bidang jasa hiburan dan sektor pariwisata. Selain adanya peningkatan pendapatan dari beberapa sektor di atas, peningkatan pendapatan juga disebabkan karena kebijakan pemerintah setempat menaikkan upah minimum pekerja, sehingga pendapatan yang diterima juga meningkat. Adanya peningkatan pendapatan ini dibarengi dengan berkurangnya jumlah penduduk miskin.

Berdasarkan hasil penelitian dan teori di atas maka dapat dikatakan bahwa pendapatan memiliki pengaruh terhadap jumlah penduduk miskin. Semakin besar pendapatan maka semakin sedikit jumlah penduduk miskin, begitu pula sebaliknya semakin rendah pendapatan maka semakin banyak jumlah penduduk miskin Jawa Timur. Dengan demikian hipotesis yang menyatakan diduga ada pendapatan berpengaruh signifikan terhadap jumlah penduduk miskin Provinsi Jawa Timur dapat diterima atau terbukti kebenarannya.

Berdasarkan hasil analisis dengan menggunakan bantuan program Eviews 6 menunjukkan hasil bahwa terdapat pengaruh signifikan antara konsumsi dengan jumlah penduduk miskin di Provinsi Jawa Timur. Hasil tersebut dibuktikan dengan hasil uji-t variabel konsumsi yang menunjukkan hasil sebesar 0,029 lebih kecil dari taraf signifikansi 0,05.Selain itu hasil juga menunjukkan bahwa hubungan antara konsumsi dengan jumlah penduduk miskin di Provinsi Jawa Timur adalah negatif atau tidak searah. Sehingga semakin tinggi konsumsi maka jumlah penduduk miskin Provinsi Jawa Timur akan menurun. Dan sebaliknya, jika semakin rendah konsumsi maka akan diikuti dengan meningkatnya jumlah penduduk miskin Provinsi Jawa Timur.

Keadaan ini sejalan dengan penelitian sebelumnya yang dilakukan oleh Gradin (2008), Moav, (2008), Vera, (2009), Gan, (2013) dan Hurd (2006) yang menyimpulkan bahwa konsumsi dapat mempengaruhi kemiskinan. Selain sejalan dengan hasil penelitian tersebut hasil penelitian ini juga sesuai dengan teori di dalam bukunnya Nicholls (2000) yang menyatakan konsumsi masyarakat menggambarkan kondisi sosialnya, kesejahteraan masyarakat bisa dilihat dari segi konsumsi mereka, sehingga tinggi rendahnya kemiskinan dipengaruhi oleh tinggi rendahnya konsumsi masyarakat.

Konsumsi beberapa Kabupaten di Jawa Timur pada 2009-2013 terus mengalami peningkatan. Peningkatan konsumsi masyarakat tidak terjadi pada konsumsi pangan namun terjadi pada konsumsi non pangan. Kebanyakan masyarakat meningkatkan konsumsi untuk mengikuti gaya hidup seperti gaya pakaian, gadget dan mengikuti prestige (gengsi) mereka. Untuk konsumsi dalam hal pangan cenderung tetap dari tahun ke tahun. Mereka menganggap bahwa dengan konsumsi non pangan yang tinggi mereka merasa derajat sosialnya tinggi. Peningkatan konsumsi masyarakat ini ternyata diikuti dengan menurunnya jumlah penduduk miskin.

Berdasarkan hasil penelitian di atas maka dapat dikatakan bahwa konsumsi memiliki pengaruh terhadap jumlah penduduk miskin. Semakin besar konsumsi 
maka semakin sedikit jumlah penduduk miskin, begitu pula sebaliknya semakin rendah konsumsi maka semakin banyak jumlah penduduk miskin Jawa Timur. Dengan demikian hipotesis yang menyatakan diduga konsumsi berpengaruh signifikan terhadap jumlah penduduk miskin Provinsi Jawa Timur dapat diterima atau terbukti kebenarannya.

Berdasarkan hasil analisis dengan menggunakan bantuan program Eviews 6 menunjukkan hasil bahwa tingkat pendidikan, pendapatan dan konsumsi berpengaruh signifikan terhadap jumlah penduduk miskin di Jawa Timur. Hal tersebut didukung dengan bukti hasil uji $\mathrm{F}$, di mana diketahui bahwa nilai signifkansi adalah sebesar 0,000000 < 0,05. Hasil ini menunjukkan bahwa variabel independen yaitu tingkat pendidikan, pendapatan dan konsumsi berpengaruh terhadap variabel dependen yaitu jumlah penduduk miskin.

Hasil analisa data juga diperoleh koefisien determinasi (R-Square) adalah sebesar 0,992350. Hal ini berarti sebesar 99,23\% jumlah penduduk miskin di Provinsi Jawa Timur dapat dijelaskan ketiga variabel tersebut, yaitu variabel tingkat pendidikan, pendapatan dan konsumsi. Sedangkan sisanya sebesar 0,77\% dipengaruhi oleh faktor-faktor lain di luar variabel penelitian.

Hasil penelitian ini sejalan dengan hasil penelitian yang dilakukan oleh Carm (2003) dan Vanderberg (2002) yang menyatakan bahwa pendidikan dan pendapatan memiliki pengaruh terhadap kemiskinan. Steiner (2002) yang menyatakan bahwa konsumsi dan pendapatan berpengaruh terhadap kemiskinan. Dan Deaton (2002) yang menyatakan bahwa konsumsi dan pendidikan berpengaruh terhadap kemiskinan.

Kenyataan yang terjadi di lapangan menggambarkan bahwa tingkat pendidikan masyarakat Jawa Timur cenderung mengalami peningkatan, yang mana dengan peningkatan ini dapat mengurangi jumlah penduduk miskin meskipun sangat sedikit penurunannya. Semakin banyak penduduk yang memiliki pendidikan minimal SMA semakin banyak penduduk yang memperoleh pekerjaan yang lebih baik. Jika seseorang memiliki pekerjaan yang lebih baik tentunya mereka juga memperoleh upah atau penghasilan yang lebih baik. Kondisi ini akan mempengaruhi pola konsumsi masyarakat. Masyarakat yang memiliki pendapatan yang lebih banyak akan membelanjakan uangnya untuk konsumsi non pangan. Karena mereka beranggapan bahwa seseorang yang bisa melakukan konsumsi non pangan dipandang memiliki derajat sosial yang tinggi.

Kondisi di atas sesuai dengan teori yang dikemukakan oleh Kuncoro (2006) yang menyatakan bahwa terdapat hubungan antara pendidikan, pendapatan dan konsumi terhadap kemiskinan. Teori ini disebut juga dengan teori lingkar kemiskinan. Semakin tinggi tingkat pendidikan akan membawa peningkatan pendapatan. Hal ini dikarenakan penduduk yang memiliki tingkat pendidikan lebih tinggi akan memperoleh pekerjaan dengan upah yang lebih besar dibandingkan penduduk yang pendidikannya rendah. Sehingga pendapatan yang mereka peroleh akan meningkat. Dengan meningkatnya pendapatan seseorang akan cenderung meningkatkan konsumsinya. Dengan meningkatnya konsumsi masyarakat maka dapat dikatakan kesejahteraan mereka juga meningkat sehingga jumlah penduduk miskin menurun.

Berdasarkan hasil penelitian dan teori di atas maka $\mathrm{H}_{0}$ ditolak, yang artinya variabel tingkat pendidikan, pendapatan dan konsumsi secara bersama-sama 
mempunyai pengaruh yang signifikan terhadap jumlah penduduk miskin di Provinsi Jawa Timur.

\section{SIMPULAN}

Tidak ada pengaruh signifikan tingkat pendidikan terhadap jumlah penduduk miskin Jawa Timur dan kedua variabel tersebut memiliki hubungan yang negatif. Berarti peningkatan tingkat pendidikan tidak diikuti dengan penurunan jumlah penduduk miskin. Hal ini ditunjukkan dengan adanya penurunan tingkat pendidikan namun tidak diikuti dengan peningkatan jumlah penduduk miskin yang signifikan.

Terdapat pengaruh signifikan pendapatan terhadap jumlah penduduk miskin Jawa Timur dan kedua variabel tersebut memilki hubungan yang negatif. Hal ini menunjukkan bahwa tingginya pendapatan dapat mengurangi banyaknya jumlah penduduk miskin Jawa Timur.

Terdapat pengaruh signifikan konsumsi terhadap jumlah penduduk miskin Jawa Timur dan kedua vaiabel tersebut memiliki hubungan yang negatif. Hal ini menunjukkan bahwa besar kecilnya konsumsi dapat mempengaruhi besar kecilnya jumlah penduduk miskin Jawa Timur.

Terdapat pengaruh signifikan tingkat pendidikan, pendapatan dan konsumsi terhadap jumlah penduduk miskin Jawa Timur. Hal ini menunjukkan bahwa ketiga variabel independen tersebut memiliki peran dalam mempengaruhi besar kecilnya jumlah penduduk miskin Jawa Timur.

\section{DAFTAR RUJUKAN}

Aksentijevic, Nada Karaman; Bogovic, Nada Denona and Jezic, Zoran. 2006. Education, Poverty and Income Inequality in the Republik of Croatia. $\mathrm{Zb}$ rad Ekon Fak Rij.

Alchian, Armen A. 2013. Cause of Poverty. Australia: Australian Laboratorion.

Appleton, Simon. 2001. Education, Income and Poverty in Uganda. Credit Research Paper, Vol. 1, No. 2, (PP: 5-20).

Arsyad, L. 2010. Ekonomi Mikro. Yogyakarta: BPFE Universitas Gajah Mada.

Blocker, Christopher P and Ruth, Julie A. 2011. Applying a Transformative Consumer Research Lens to Understanding and Alleviating Poverty. Journal of Research for Consumer, Vol. 19, No. 1, (PP: 1-9).

Bloom, David; Canning, David and Chan, Kevin. 2006. Higher Education and Economic Development in Africa. Human Development Research, Vol. 5, No. 1, (PP: 25-90).

BPS. 2013. PDRB Provinsi Jawa Timur. Jawa Timur: BPS.

BPS. 2013. susenas. Jawa Timur: BPS.

Brown, Philip H and Park, Albert. 2002. Education and Poverty in Rural China. Economic of Education Review, Vol. 21, No. 6, (PP: 523-541). 
Capra, T. 2009. Poverty and Its Impact on Education. The Nea Higher Education Journal, Vol. 25, No. 1, (PP: 78-111).

Carm, Ellen. 2003. Education, Income, and Its Impact on Poverty. International Education Journal Centre at Oslo University, Vol. 7, No. 2, (PP: 50-72).

Case, K., \& Fair, R. 2002. Principle Of Economic. Jakarta: Prenhalindo.

Deaton, Angus. 2002. Consumption, Education and Poverty. Princenton University Research,Vol.1, No. 1, (PP: 35-53).

Doshi, K. P. 2000. Inequality and Economic Growth. San Diego: University of San Diego.

Gan, Li. 2013. The Challenge of High Inequality in China. Inequlity in Focus, Vol. 1 No. 2, (PP: 1-20).

Gerson, P. 2002. Poverty and Consumption in the Philippines. IMF Working Paper, (PP: 1-27).

Gillis, Malcom. 2000. Economic of Development. New York: WW Norton \& Company Inc.

Gradin, Carlos. 2008. Inequality Poverty and Mobility: Choosing Income or Consumption as Walfare Indicator. Investigaciones Economicas, (PP: 297339).

Harbison, F. 2000. Perencanaan Pendidikan dan Sumber Daya Manusia. Jakarta: Bhratara Karya Aksara.

Hurd, Michael D and Rohwedder, Susana. 2006. Income and Consumption Based Poverty Measures. National Bureau of Economic Research, (PP: 1-34).

Ihsan, F. 2011. Perkembangan Peserta Didik. Jakarta: Rineka Cipta.

Janjua, Pervez Zamurrad 2011. The Role of Education and Income in Poverty Alleviation. The Lahore Journal of Economics, Vol. 16, No. 1, (PP: 143172).

Kambon, Asha. 2000. Education and its Impact on Poverty Equity or Exclusion. UNESCO Representative in the Caribbean, (PP: 1-49).

Kuncoro, M. 2006. Ekonomika Pembangunan: Teori, Masalah dan Kebijakan. Yogyakarta: UPP STIM YKPN.

Lacour, M. 2011. Effect of Academic on Poverty. Educational Research and Reviews, (PP: 522-527).

Law, NM Center and Poverty. 2014. Alleviating Poverty Will Improve Education In New Mexico. Kellogg Foundation, (PP: 1-20)

Mankiw, N. Gregory. 2013. Pengantar Ekonomi Makro. Jakarta: Salemba Empat.

Moav, Omer. 2008. Conspicuous Consumption, Human Capital and Poverty. JEL, Vol. 1, No. 2, (PP: 1-31).

Nicholls, Lucius Sediaoetama. .2000. Konsumsi Masyarakat Daerah. Jakarta: Balai Pustaka. 
Nurhadi. 2000. Pengaruh Pendapatan terhadap Tingkat Konsumsi. Jurnal Ekonomi Pembangunan, Vol. 1, No. 1, (PP: 1-31).

Raphael, D. 2002. Poverty and Income in Canada. CSJ Foundation, (PP: 135175).

Rika, Darma. 2012. Pengaruh Tingkat Pendidikan, Pendapatan per Kapita dan Pengangguran Terhadap Kemiskinan di DKI Jakarta, Econosains, Vol. 10, No. 2, (PP: 17-30).

Rosydi, Suherman. 2002. Pengantar Teori Ekonomi. Jakarta: Raja Grafindo Persada.

Samuelson, Paul. 2004. Mikro Ekonomi. Jakarta : Erlangga.

Singh, R. 2012. Human Development Index and Poverty Linkages. International Journal of Marketing and Technology, Vol. 2 No. 5, (PP: 219-288).

Steiner, Achim. 2002. Consumption and Income for Poverty Eradication. International Economics Journal,Vol. 16, No. 1, (PP: 45-60).

Sudjana. 2005. Metoda Statistika. Bandung: Tarsito.

Sugiyono. 2011. Statistik Untuk Penelitian. Bandung: Alfabeta.

Sukirno, S. 2004. Pengantar Teori Makro Ekonomi. Jakarta: Raja Grafindo Persada.

Sukirno, S. 2006. Ekonomi Pembangunan; Proses, Masalah dan Dasar Kebijakan. Jakarta: Kencana Prenada Media Group.

Suryana. 2000. Ekonomi Pembangunan. Jakarta: Salemba Empat.

Teal, Francis. 2001. Education, Income, Poverty and Inequality in Ghana, JEL, Vol. 21, No. 1, (PP: 1-32).

Todaro, Michael P; Smith, C Stephen. 2006. Ekonomi Pembangunan. Jakarta: Erlangga.

Ukwueze, Ezebuilo; Emmanuel, Nwosu. 2014. Does Higher Education Reduce Poverty Among Youth in Nigeria. Asian Economic and Financial Review, Vol. 4, No. 1, (PP: 1-19).

Vanderberg, Servaas. 2002. Education, Income, Inequality and Poverty in South Africa. Center Study of African Economies, (PP: 1-26).

Vera, Lisna. 2009. Analisis faktor-faktor ekonomi makro yang mempengaruhi tingkat konsumsi era pemerintahan SBY jilid I. EPN IPB, Vol. 7, No. 3, (PP: 3-15).

Wahyu, T. 2011. Identifikasi Faktor Penyebab Kemiskinan. Jurnal Ekonomi Pembangunan, Vol. 12, No. 1, (PP: 28-44).

Zakharia, Z. 2006. Education and Poverty in an International Context. Society for International Education Teacher College Columbia University, (PP: 15$35)$. 